\title{
POSSIBLE TEST METHODS FOR THE EXAMINATION OF THE LEACHING BEHAVIOUR OF A GEOPOLYMER RAW MATERIAL
}

\author{
Mária Ambrus \\ PhD student, University of Miskolc, Institute of Raw Material Preparation and Environmental Processing \\ 3515 Miskolc, Miskolc-Egyetemváros, e-mail: maria.ambrus@uni-miskolc.hu
}

\section{Gábor Mucsi}

Professor, University of Miskolc, Institute of Raw Material Preparation and Environmental Processing 3515 Miskolc, Miskolc-Egyetemváros, e-mail: ejtmucsi@uni-miskolc.hu

\begin{abstract}
Fly ash is an industrial by-product which is deposited in high quantities worldwide, but the use as raw material for geopolymer production would be a feasible option to eliminate not only the possible environmental damages, but the extensive land usage for the deposits. In the article, various extraction methods are summarised that could be applicable to evaluate the leaching behaviour of fly ash, based on the intended final use.
\end{abstract}

Keywords: elemental composition, fly ash, leaching processes, test methods

\section{Introduction}

Coal is primarily used as fuel for the production of electricity and is one of the most prominent part of the energy mix worldwide. Even though the use of renewable energy sources is encouraged, the amount of coal consumption was over 5000 Mtce in 2019, with China, India and the USA being the biggest consumers. As a result of coal usage, high amounts of coal combustion by-products are being produced as well $[1,2]$.

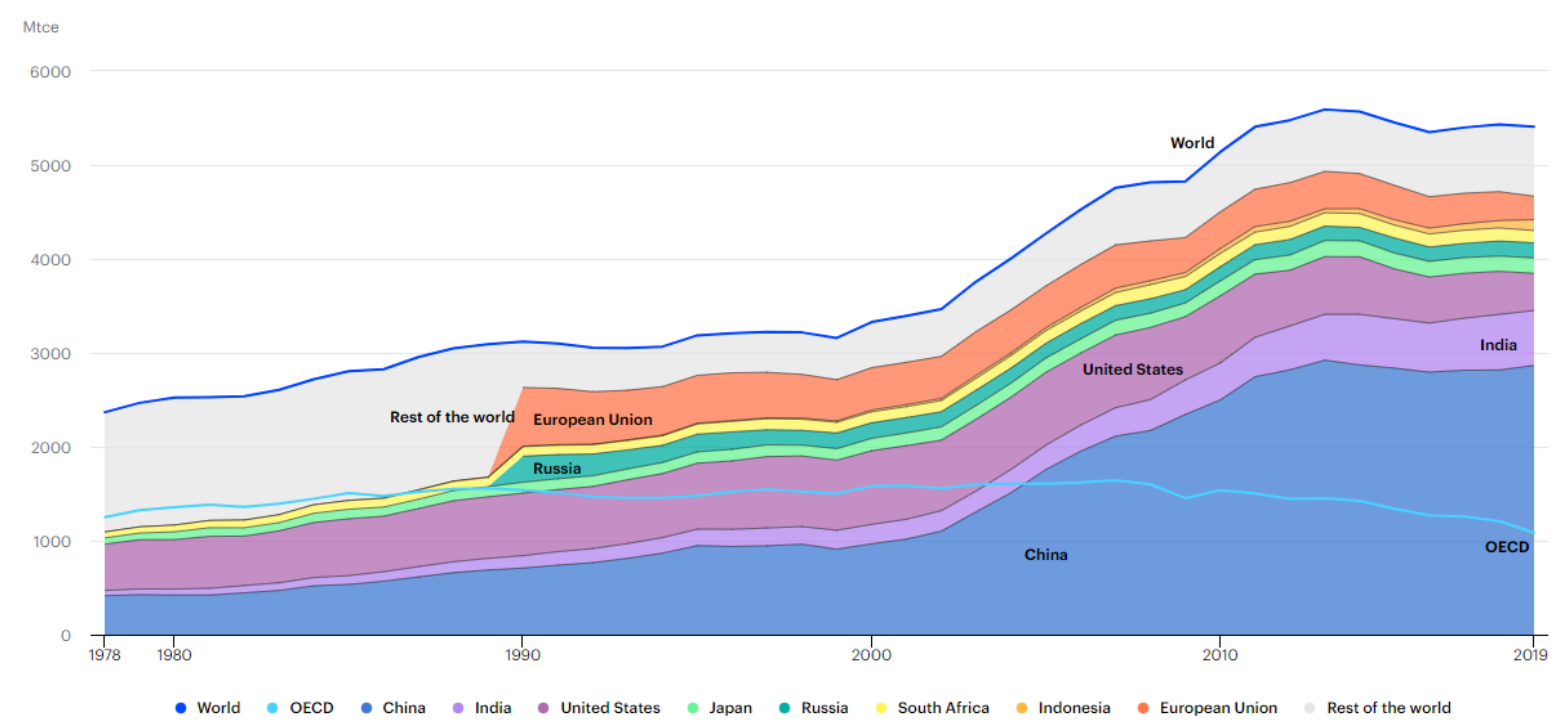

Figure 1. World coal consumption between 1978-2019 [2] 
In accordance with coal consumption, there are three main countries that are responsible for the production of high amounts of fly ash. The third highest fly ash producer is the USA with over 38 short tons ( $\sim 35$ metric tons) in 2017 [3], the second is India with almost 170 million tons generated between April 2016 and March 2017 [4], and finally, the highest amount is produced in China, reaching annually 600 million tons by 2015 [5]. In case of the EU-15 countries, a decrease can be detected in the production of coal combustion products in the last 20 years. The highest amount of coal combustion products is fly ash, the quantity of which decreased from 40 million tonnes in 1997 to $\sim 25$ million tonnes in 2017 [6].

As only a small portion of fly ash is utilised, compared to the vast amount that is produced, high quantities are deposited into ponds, lagoons or landfills. The environmental concerns about fly ash disposal mainly focus on the potential soil and water pollution due to the release of harmful elements and compounds via leachate. There are various possible contaminants in fly ash, and the mineralogical and chemical composition is highly dependent on many factors, including for example the composition and type of coal used in the power plants, technology used for coal mining, combustion parameters, and the storage type and time of fly ash etc. Some elements occurring in coals are highly volatile (i.e.: As, $\mathrm{Ba}, \mathrm{Br}, \mathrm{Co}, \mathrm{Cr}, \mathrm{Ga}, \mathrm{Hg}, \mathrm{Ln}, \mathrm{Mn}, \mathrm{Nd}, \mathrm{Ni}, \mathrm{Pb}, \mathrm{S}, \mathrm{Sb}, \mathrm{Se}, \mathrm{Sn}, \mathrm{V}, \mathrm{Zn}$ ), certain elements have smaller fractions volatilised during combustion (i.e.: $\mathrm{Ce}, \mathrm{Cs}, \mathrm{K}, \mathrm{Mg}, \mathrm{Mo}, \mathrm{Nb}, \mathrm{Rb}$ ). Furthermore, elements like Ag, Ca, Eu, Fe, La, Na, Py, Se, Si, Sm, Sr, Ta, Tb, Y, Yb, Zn and Zr are typically not volatilised. Because of evaporation and condensation processes, some of the trace elements in coal are enriched and associated with the surface of fly ash particles $[1,7]$. The average chemical composition of various types of fly ashes are summarised in Table 1.

Table 1. Average composition of fly ashes produced from various coals [8]

\begin{tabular}{|c|c|c|c|}
\hline Component & Bituminous, wt.\% & Subbituminous, wt.\% & Lignite, wt.\% \\
\hline $\mathrm{SiO}_{2}$ & $20-60$ & $40-60$ & $15-45$ \\
\hline $\mathrm{Al}_{2} \mathrm{O}_{3}$ & $5-35$ & $20-30$ & $10-25$ \\
\hline $\mathrm{Fe}_{2} \mathrm{O}_{3}$ & $10-40$ & $4-10$ & $4-15$ \\
\hline $\mathrm{CaO}$ & $1-12$ & $5-30$ & $15-40$ \\
\hline $\mathrm{MgO}$ & $0-5$ & $1-6$ & $3-10$ \\
\hline $\mathrm{SO}_{3}$ & $0-4$ & $0-2$ & $0-10$ \\
\hline $\mathrm{Na}_{2} \mathrm{O}$ & $0-4$ & $0-2$ & $0-6$ \\
\hline $\mathrm{K}_{2} \mathrm{O}$ & $0-3$ & $0-4$ & $0-4$ \\
\hline $\mathrm{LOI}$ & $0-15$ & $0-3$ & $0-5$ \\
\hline
\end{tabular}

Due to the relatively high reactive silica and alumina content, fly ash has a great potential as raw material for geopolymer production. Geopolymers are inorganic aluminosilicate polymers, that can be produced with the combination of an activator media and solid silica and alumina bearing materials at near ambient temperatures. The resulting material has reasonable mechanical properties, fire and acid resistance, good thermal stability etc. As most of the produced fly ash is deposited, the utilisation may be hindered by the chemical changes taking place due to the exposure to the environmental conditions for a prolonged time $[9,1011]$. Thus, various leaching methods have been prepared to examine the elemental composition and leaching behaviour of fly ash. 


\section{Fly ash leaching test methods}

Various methods have been developed by different organisations and researchers to examine the leaching behaviour of coal combustion by-products during the past decades. However, in some cases extraction procedures designed for e.g.: soils or other solid wastes can also be used to examine fly ash leaching parameters. After the various extractions, different analytical methods are used to examine the leached elements in the obtained fractions.

\subsection{Guidelines of the International Atomic Energy Agency (IAEA)}

Based on the IAEA guidelines, standard leaching tests for various coal combustion residues can be carried out. After taking samples and drying the material at $105^{\circ} \mathrm{C}$ to constant weight, the particle size should be reduced to $<3 \mathrm{~mm}$ for the better reproducibility of the results. Before testing, the size reduction of the sample can be done with sieving or crushing, but grinding should be avoided [12].

\subsubsection{Acidity test}

Acidity test is relevant if short-term leaching of the material is to be examined, related to the primary reactions of ashes with water.

To determine the acid-base behaviour of the sample, first, $5.0 \mathrm{~g}$ material should be placed in a $1000 \mathrm{~mL}$ beaker with $500 \mathrm{~mL}$ demineralised or distilled water. After 60 seconds of stirring the $\mathrm{pH}$ ( $1 \mathrm{~min})$ should be recorded. Then, followed by 9 minutes of stirring the $\mathrm{pH}(10 \mathrm{~min})$ should be recorded. The sample is considered "acid" if the $\mathrm{pH}(10 \mathrm{~min})$ is $<7$, "alkaline" if the $\mathrm{pH}(1 \mathrm{~min})$ is $>10$, and the materials not included in the two categories are "neutral" [12].

\subsubsection{Shake test and cascade shake test}

Shake test and cascade shake tests are appropriate to examine the short-term leaching of ashes. In case of the shake test, the precipitation of secondary compounds and adsorption processes can be simulated, while the cascade shake test can give information on the redissolution of secondary compounds.

The first step during the procedure is to acidulate $4.5 \mathrm{~L}$ of water with nitric acid until $\mathrm{pH}=4$ is reached, and store $0.5 \mathrm{~L}$ water as a blank. Then $40 \mathrm{~g}$ of the test material should be placed in a $1 \mathrm{~L}$ polyethylene bottle with $0.8 \mathrm{~L}$ of the prepared acidified water. After 23 hours of agitation, the mixture should be allowed to settle for 15 minutes and then decanted through a $0.45 \mathrm{~mm}$ membrane filter. The $\mathrm{pH}$ and the conductivity of the filtrate should be measured and recorded, and the composition analysed along with the blank sample. Next, the water should be acidulated with nitric acid to $\mathrm{pH}=2$. Using the same ash sample, the next 23-hour extraction can be performed, until five extractions are completed:

- Fraction 1: $\mathrm{L} / \mathrm{S}=20$;

- Fraction 2: $\mathrm{L} / \mathrm{S}=40$ - cumulative;

- Fraction 3: L/S=60 - cumulative;

- Fraction 4: $\mathrm{L} / \mathrm{S}=80$ - cumulative;

- Fraction 5: L/S=100 - cumulative [12].

\subsubsection{Column test}

Similarly to the cascade shake test, the column test is suitable to examine the short-term leaching of materials, and the process involved during this time is the redissolution of secondary compounds.

A dried column with $50 \mathrm{~mm}$ internal diameter, and minimum $200 \mathrm{~mm}$ height should be filled with the tested material to a bed height at least $4 \times$ of the column diameter, using a $0.45 \mathrm{~mm}$ membrane filter at both the bottom and the top of the bed. Then, the weight of the added material, thereafter, 
denoted with $\mathrm{G}$, should be determined. The next step is to measure demineralised or demineralized double distilled water $(10 \times \mathrm{G}+0.1 \mathrm{~L})$ and acidulated with $\mathrm{HNO}_{3}$, until $\mathrm{pH}=4$ is achieved. $0.1 \mathrm{~L}$ of the acidified water should be stored as a blank sample. A peristaltic pump with $0-50 \mathrm{~mL} / \mathrm{h}$ capacity should be adjusted to a $\mathrm{G} / 48[\mathrm{~L} / \mathrm{h}]$ throughput, and the delivery side should be connected to the bottom of the column, while the top of the column should be connected to a receiving bottle [12]. The following fractions should be produced:

- Fraction 1: $0.1 \times \mathrm{G}$ litres $(\mathrm{L} / \mathrm{S}=0.1)$;

- Fraction 2: $0.4 \times \mathrm{G}$ litres $(\mathrm{L} / \mathrm{S}=0.5)$;

- Fraction 3: $0.5 \times \mathrm{G}$ litres $(\mathrm{L} / \mathrm{S}=1.0)$;

- Fraction 4: $1.0 \times \mathrm{G}$ litres $(\mathrm{L} / \mathrm{S}=2.0)$;

- Fraction 5: $1.0 \times \mathrm{G}$ litres $(\mathrm{L} / \mathrm{S}=3.0)$;

- Fraction 6: $2.0 \times \mathrm{G}$ litres $(\mathrm{L} / \mathrm{S}=5.0)$;

- Fraction 7: $5.0 \times \mathrm{G}$ litres $(\mathrm{L} / \mathrm{S}=10.0)$.

After the collection of the fractions, the $\mathrm{pH}$ and conductivity should be measured, and the fraction should be acidulated with $\mathrm{HNO}_{3}$ to $\mathrm{pH}=2$ [12].

\subsection{The National Energy Technology Laboratory method}

The leaching method developed by National Energy Technology Laboratory of the US Department of Energy is a serial batch leaching procedure at static $\mathrm{pH}$ values, specifically prepared for the examination of coal fly ash.

The method includes criteria related to conditions controlling leachability, various fly ash properties, such as particle size, alkalinity, etc, and imitates natural environmental conditions. It can be used to obtain data about the total leachable material content (availability) and elemental extraction rate (long term leaching), in relation to the liquid/solid ratio (L/S) $[1,13]$. To test availability, the leaching steps for alkaline samples are the following:

- Place $9 \mathrm{~g}$ alkaline ash sample in $450 \mathrm{~mL}$ distilled $\mathrm{H}_{2} \mathrm{O}, \mathrm{L} / \mathrm{S}=50$;

- Use magnetic stirring at $250 \mathrm{rpm}$, at the natural $\mathrm{pH}$ of the ash for 2 hours, filter at $0.45 \mu \mathrm{m}$;

- Measure natural $\mathrm{pH}$ and analyse leachate;

- Add fresh liquid to the fly ash, with maintaining pH at 8 using $\mathrm{HNO}_{3}$, stir for 3 hours, then filter;

- Repeat the procedure with $\mathrm{pH} 4$ for 2 hours, then filter;

- Repeat with $\mathrm{pH} 2$ for 2 hours [13].

The availability test can also be applied for acidic samples. Two parallel tests should be carried out: in one case, $9 \mathrm{~g}$ of sample should be leached at the initial $\mathrm{pH}$ for 3 hours, then at $\mathrm{pH}=4$ for 2 hours, and then at $\mathrm{pH}=2$ for 2 more hours; in the other experiment, a new sample is to be leached at the initial $\mathrm{pH}$ for 4 hours, and then at $\mathrm{pH}=8$ for 3 hours [14]. For the simulation of long-term exposure, the undermentioned steps are described according to the serial batch leaching procedure:

- Place $45 \mathrm{~g}$ sample in $90 \mathrm{~mL}$ distilled $\mathrm{H}_{2} \mathrm{O}, \mathrm{L} / \mathrm{S}=2$;

- Use a bottle roller for 6 hours, filter at $0.45 \mu \mathrm{m}$;

- Measure $\mathrm{pH}$ and analyse leachate;

- Add fresh liquid to the fly ash with $\mathrm{L} / \mathrm{S}=8$, use bottle roller for 18 hours, then filter;

- Repeat the procedure with $\mathrm{L} / \mathrm{S}=10$, use bottle roller for 24 hours;

- Use a separate, $10 \mathrm{~g}$ sample and place in $1 \mathrm{~L}$ distilled $\mathrm{H}_{2} \mathrm{O}, \mathrm{L} / \mathrm{S}=100$;

- Use a bottle roller for 24 hours, filter and analyse the leachate $[1,13]$. 


\subsection{Synthetic groundwater leaching procedure}

The synthetic groundwater leaching procedure was developed at the University of North Dakota Energy and Environmental Research Center and is applicable to simulate field leaching conditions for various coal combustion by-products.

For the experiments, $100 \mathrm{~g}$ solid sample is dissolved in $2 \mathrm{~L}$ of deionised water $(\mathrm{L} / \mathrm{S}=20)$. The containers with the mixture are rotated end-over-end at $30 \mathrm{rpm}$ for 18 hours, then the $\mathrm{pH}$ should be measured, and the leachate analysed. For long term measurements, the extraction should be repeated for 30 and 60 days [1,13].

\subsection{Mine water leaching procedure}

The process was developed at the West Virginia Water Research Institute National Mine Reclamation Center, aiming at the examination of ashes in acidic media.

The tests are carried out with $100 \mathrm{~g}$ sample in $2 \mathrm{~L}$ of mine water, or $0.002 \mathrm{M} \mathrm{H} 2 \mathrm{SO} 4$ solution $(\mathrm{L} / \mathrm{S}=20)$ agitated at $30 \mathrm{rpm}$ for 18 hours. Then, the mixture is filtered at $0.7 \mu \mathrm{m}$, then rinsed back into a container with $2 \mathrm{~L}$ fresh solution. These steps are repeated until the leachate $\mathrm{pH}=3$ [11].

\subsection{Sequential extraction procedure}

In their article, Tessier et al. aimed at developing a sequential selective extraction method to partition trace metals into chemical forms in which they are presumably released in solution under different environmental conditions. The procedure was not specifically designed for testing fly ash, but solid sediment samples in general. However, the fractions determined for the experiments could be applied to examine a wide range of materials. The samples used for the experiments were stored at $4{ }^{\circ} \mathrm{C}$ for no longer than 3 days before drying them at $105^{\circ} \mathrm{C}$, ground in a mortar, homogenised and stored at $4{ }^{\circ} \mathrm{C}$ until use. The experiments were performed on $1 \mathrm{~g}$ of sample (which is the dry weight of the original sample) [15]. The following fractions and extracting solutions were selected:

- Fraction 1 - exchangeable elements: the extraction step relies on the observation that the ionic composition of water can affect the sorption and desorption processes, thus, for the tests the sample can be extracted with $8 \mathrm{~mL}$ of either $1 \mathrm{M}$ magnesium chloride solution $(\mathrm{pH}=7.0)$ or $1 \mathrm{M}$ sodium acetate solution $(\mathrm{pH}=8.2)$ with continuous agitation at room temperature for 1 hour.

- Fraction 2 - elements bound to carbonates: such elements are likely to be affected by changes in $\mathrm{pH}$, so for this process the solid residue from fraction 1 is leached in $8 \mathrm{~mL}$ of $1 \mathrm{M}$ sodium acetate solution, while acetic acid is applied to adjust the $\mathrm{pH}$ to 5 . The leaching is carried out at room temperature and continuous agitation is used. The duration of the agitation depends on factors such as the amount and type of carbonate species, the particle size and quantity of the sample. According to the results, 5 hours of extraction should be sufficient for most samples.

- Fraction 3 - elements bound to Fe-Mn oxides: Fe and Mn oxides are thermodynamically unstable under anoxic conditions, and for the extraction the sample is transferred to a mixture of $20 \mathrm{~mL}$ of either $0.3 \mathrm{M} \mathrm{Na}_{2} \mathrm{~S}_{2} \mathrm{O}_{4}+0.175 \mathrm{M} \mathrm{Na}$-citrate $+0.025 \mathrm{M} \mathrm{H}$-citrate or $0.04 \mathrm{M}$ $\mathrm{NH}_{2} \mathrm{OH} \cdot \mathrm{HCl}$ in $25 \mathrm{v} / \mathrm{v} \%$ acetic acid solution for at $96 \pm 3{ }^{\circ} \mathrm{C}$ for 6 hours, with occasional agitation.

- Fraction 4 - elements bound to organic matter: if the organic matter is degraded, e.g. under oxidising conditions, the soluble elements can be released. For this fraction, the solid sample from fraction 3 is added to $3 \mathrm{~mL}$ of $0.02 \mathrm{M} \mathrm{HNO}_{3}$ and $5 \mathrm{~mL}$ of $30 \% \mathrm{H}_{2} \mathrm{O}_{2}$, the $\mathrm{pH}$ is adjusted to 2 using $\mathrm{HNO}_{3}$. The mixture is heated to $85 \pm 2{ }^{\circ} \mathrm{C}$ for 2 hours with intermittent stirring. Next, 
$3 \mathrm{~mL}$ of $30 \% \mathrm{H}_{2} \mathrm{O}_{2}$ is added to the mixture and heated to $85 \pm 2{ }^{\circ} \mathrm{C}$ for 3 more hours with occasional agitation. Then, the mixture is cooled down, $5 \mathrm{~mL}$ of $3.2 \mathrm{M} \mathrm{NH}_{4} \mathrm{OAc}$ in $20 \mathrm{v} / \mathrm{v} \%$ $\mathrm{HNO}_{3}$ was added and continuously stirred for 30 minutes.

- Fraction 5-residual material: these elements should not be leached under typical environmental conditions. For analysis, the residual sample is leached in a 5:1 mixture of $\mathrm{HF}^{-} \mathrm{HClO}_{4}$ [15].

\subsection{Batch leaching tests}

A series of batch leaching tests was conducted by Ugurlu to examine the leaching characteristics of fly ash by simulation natural environmental conditions and predict the possibility of pollution via leaching. Using $5 \mathrm{~g}$ fly ash sample and $25 \mathrm{~mL}$ deionised water $(\mathrm{L} / \mathrm{S}=5)$, the experiments were performed at room temperature, 40 and $50{ }^{\circ} \mathrm{C}$ with continuous stirring for 2 hours. Three subsequent extractions were carried out during the 2 hours, using the same volume for each extraction [7].

The technique to analyse the leachate is not specified by any of the abovementioned leaching procedures, but a variety of methods can be applied, such as atomic adsorption spectrophotometry, inductively coupled plasma atomic (optical) emission spectroscopy (ICP-OES), inductively coupled plasma mass spectrometry (ICP-MS) or laser induced breakdown spectroscopy $[1,13,16]$.

\section{Summary}

Based on the literature, numerous extraction methods have been developed during the past decades related to the evaluation of leaching characteristics of fly ash, combustion by-products and other solid materials. Most of the leaching procedures can produce comparable results, however, the time frame of the experiments is different: from a few hours to up to 60 days if long term leaching characteristics are to be tested. Some of the extraction processes put emphasis on the changes in the liquid-to-solid ratio at each extraction steps, e.g. the tests in the IAEA guidelines, while others, like the sequential selective extraction method, reflect on the different environmental conditions that can influence fly ash leaching. From the examined techniques, a prominent drawback of synthetic groundwater leaching procedure might be that only the natural $\mathrm{pH}$ is used for extraction. Thus, depending on the available materials and conditions to be simulated, the choice of the appropriate method should be made before carrying out experiments related to fly ash leaching behaviour.

\section{Acknowledgements}

The research reported here was carried out as part of the EFOP-3.6.1-16-2016-00011 "Younger and Renewing University - Innovative Knowledge City - Institutional development of the University of Miskolc aiming at intelligent specialization" project implemented in the framework of the Szechenyi 2020 program. The realization of this project is supported by the European Union, co-financed by the European Social Fund.

\section{References}

[1] Kim, A. G., Hesbach, P.: Comparison of fly ash leaching methods, Fuel, 88(5), (2009) pp. 926937. https://doi.org/10.1016/j.fuel.2008.11.013

[2] https://www.iea.org/data-and-statistics/charts/world-coal-consumption-1978-2019

[3] American Coal Ash Association: Coal ash recycling reaches record 64 percent amid shifting production and use patterns, Press release, published: November 13, 2018. 
[4] Thakur, G.: Report on fly ash generation at coal/lignite based thermal power stations and its utilization in the country for the year 2016-17. New Delhi, 2017.

[5] Ma, S.-H., Xu M.-D., Qiqige, Wang, X-H., Zhou, X.: Challenges and developments in the utilization of fly ash in China, International Journal of Environmental Science and Development, 8(11), (2017) pp. 781-785. https://doi.org/10.18178/ijesd.2017.8.11.1057

[6] Skidmore, I., Feuerborn, H.-J.: Developments in CCP management in Europe, 2019. In: McCarthy, M. J., Newlands, M. D., Jones, M. R., Dyer, T. D., Csetenyi, L. J., Zheng, L. (eds): EuroCoalAsh 2019 Proceedings, Dundee, Scotland, United Kingdom, pp. 18-30.

[7] Ugurlu, A.: Leaching characteristics of fly ash. Environmental Geology, 46(6-7), (2004) pp. 890-895. https://doi.org/10.1007/s00254-004-1100-6

[8] https://www.fhwa.dot.gov/publications/research/infrastructure/structures/97148/cfa51.cfm

[9] Mackenzie, K. J. D., Welter, M.: Geopolymer (aluminosilicate) composites: synthesis, properties applications, In: Low, I. M. (ed): Advances in Ceramic Matrix Composites, 2014, Woodhead Publishing Limited. https://doi.org/10.1533/9780857098825.3.445

[10] Kumar, S., Mucsi, G., Kristály, F., Pekker, P.: Mechanical activation of fly ash and its influence on micro and nano-structural behaviour of resulting geopolymers, Advanced Powder Technology 28(3), 2017, pp. 805-813. https://doi.org/10.1016/j.apt.2016.11.027

[11] Mucsi, G., Szabó, R., Ambrus, M., Kovács, B.: The development of fly ash-red mud based geopolymer, Analecta Technica Szegedinensia 12(1), (2018) pp. 30-38. https://doi.org/10.14232/analecta.2018.1.30-38

[12] https://inis.iaea.org/collection/NCLCollectionStore/_Public/22/083/22083122.pdf?r=1\&r=1

[13] Hesbach, P., Burgers, C., Greiner, A., Hassett, D. J., Heebink, L. V., Beck, M., Eick, M., Daniels, L.: Inter-laboratory Comparison of Leaching Methods, 2005 World of Coal ash (WOCA), April 11-15, 2005, Lexington, Kentucky, USA.

[14] Hesbach, P. A., Kim, A. G., Abel, A. S. P., Lamey, S. C.: Serial batch leaching procedure for characterization of coal fly ash, Environmental Monitoring and Assessment, 168(1-4), (2009) pp. 523-545. https://doi.org/10.1007/s10661-009-1132-1

[15] Tessier, A., Campbell, P. G. C., Bisson, M.: Sequential extraction procedure for the speciation of particulate trace metals, Analytical Chemistry, 51(7), (1979) pp. 844-851. https://doi.org/10.1021/ac50043a017

[16] Mucsi, G., Szenczi, Á., Molnár, M., Lakatos, J.: Structural formation and leaching behaviour of mechanically activated lignite fly ash based geopolymer, Journal of Environmental Engineering and Landscape Management, 24(1), (2016) pp. 48-59.

https://doi.org/10.3846/16486897.2015.1106406 